\title{
The most prevalent obstacles on the way of constructing effective teachers-students interaction and the reasons of their emersion
}

\author{
S. D. Isaieva \\ Taras Shevchenko National University of Kyiv, Ukraine \\ Corresponding author. E-mail: lana.dm.isv@gmail.com
}

Paper received 02.05.20; Accepted for publication18.05.20.

https://doi.org/10.31174/SEND-PP2020-229VIII93-02

\begin{abstract}
The possible problems of teachers-students pedagogical interaction are studied in the article. The inextricable link between pedagogical interaction and pedagogical communication, which is a part of the complex process of modern educational development, is underlined. The pedagogical heritage of the American scientist Thomas Gordon is explored, namely: his views concerning the main obstacles on the way of building effective pedagogical interaction, and the potential opportunities for overcoming them.
\end{abstract}

Keywords: Thomas Gordon, pedagogical interaction, pedagogical communication, teachers, students, obstacles.

Introduction. Pedagogical interaction and pedagogical communication between teachers and students, as participants in the educational process, are aimed at creating the optimal conditions for the implementation of the educative and educational goals and objectives.

Pedagogical communication plays a huge role in the process of teaching young people. Without it it is impossible to implement neither the effective education of each person, nor interpersonal contacts in general. Pedagogical communication plays an important role in students' mastering universal values and social experience.

In the process of pedagogical communication, during the interaction between teachers and students, the exchange of their ideas, interests and emotional mood takes place.

The amplification of the significance of pedagogical communication in the modern world requires the teachers' ability to communicate effectively, that implies the necessity of teachers' deep knowledge of the laws and features of this phenomenon.

In order to improve the efficiency of pedagogical communication, it is important for teachers not only to be able to speak and distribute the necessary information, but also to be able to listen, hear and understand what students say.

Pedagogical communication is inseparably linked with pedagogical interaction, which is a part of the complex and contradictory process of modern education development.

Taking into account all the current changes in the economical, political, social and other spheres of Ukrainian society's life, it should be noted that the new tasks are being put forward before educational system in accordance with the requirements of the present time.

Short review of the publications on the subject. The search for solutions to the problem of pedagogical interaction can be traced in the works of such modern Ukrainian scholars as O. Druganov, O. Gluzman, V. Kurylo, O. Mykytiuk, S. Mykytiuk, V. Mayborodova, N. Pobirchenko, N. Puzyrkova, O. Ratsul, M. Yevtukh, S. Zolotukhina and others [4].

The emotional and communicative side of learning interaction were analyzed by E. Belenkina, V. Kotova, M. Rybakova, M. Sedova, R. Shakurova, L. Zharova and others [3].

The problems of pedagogical interaction were studied by G. Bal, L. Kondrashov, M. Leshchenko, L. Nechayeva,
M. Viyevska, V. Vlasenko, I. Zyazyun [5]. The ways of forming the teacher's individual style of pedagogical communication were sought by A. Andreyev, V. Haluziak, G. Meshko [2]. The process of forming communicative skills and abilities was studied by Z. Bilousova, V. Kaplynsky, N. Kosova, M. Kots, I. Kyrylova, T. Shepelenko, M. Vasyliev.

Many foreign scholars considered interaction in learning from the point of view of the provisions of humanistic and cognitive psychology. The American scientist Thomas Gordon was one of those who explored the causes of ineffective pedagogical interaction and the consequences of negative pedagogical communication, and offered his own ways to overcome them. Nevertheless, his pedagogical heritage for a long time remained out of the scientists' attention.

Thus, the purpose of the article is to highlight the main obstacles on the way of constructing an effective pedagogical interaction between teachers and students according to Thomas Gordon's point of view, and to consider the reasons of their emersion. We believe that the analysis of existing obstacles is an important step towards finding new ways of their overcoming.

Presenting main material. According to Thomas Gordon, some of the most important obstacles on the way of establishing a positive relationship between teachers and students are: 1) the image of the ideal teacher; 2) the level of teacher's tolerance; 3 ) factors that determine the teacher's perception of the student; 4) demonstrative teacher's exactingness / non-exactingness to the student, depending on the situation; 5) misunderstanding of the affiliation of the problem.

So, from Thomas Gordon's point of view, the first obstacle is the image of the ideal teacher. According to traditional ideas, there is the assumption that teachers should be smarter and better than ordinary people. Unfortunately, such a viewpoint does not give the teacher the opportunity to remain an ordinary person, and therefore deprives him of human features.

As for the second obstacle, Thomas Gordon distinguished the level of teacher's tolerance. The scholar noted that teachers can be tolerant and intolerant. An important point is that some of them set high requirements for students, as well as, in particular, for any other people. Such teachers are rarely satisfied with students' natural behavior in the auditorium as they have a steady idea of how students should behave. Students perceive such teachers 
too stern, they do not like their leadership tone and therefore they try to avoid any communication $[1,26]$. Tolerant teachers try to condemn students less, show more flexibility, and substantially expand the boundaries of admissible students' behavior. They rarely impose their opinions, accept any human qualities of students [1, 27]. Teachers, who often scold or criticize students, consider this approach constructive one. They are convinced that it helps students to behave better. However, exactly the opposite is true. Conviction and giving bad marks prevent the students from changing and do not contribute to correcting their behavior. Students treat such teachers with particular circumspection, sometimes behaving in such a way as to irritate teachers even more, and their appeals to the orderliness and discipline in similar situations unfortunately do not contribute to the educational process [1, 27-28].

The third obstacle, in Thomas Gordon's opinion, is the factors that influence students' perception by teachers. Sometimes there are situations when at some moment even the most patient teacher becomes impatient, and the behavior of students, which previously seemed quite acceptable to him, suddenly becomes unacceptable. Thus, the scientist outlined three main factors, which influence on teachers' perception of the students, namely: a) changes in the teacher; b) different teacher's attitudes to different students; c) changes in the environment or situation [1, 28-29].

As Thomas Gordon pointed out, people differently react to other people, as it depends on their mood, health state or other reasons, and moreover is often not related to other people's behavior, which may remain unchanged. As to the changes in the teacher about which Thomas Gordon said, all of them (the teachers) are alive people, not hard-hearted robots, and therefore they also can respond to everything in different ways [1, 30-32].

Concerning the attitude towards students, teachers can treat them differently and there are many reasons for this. For example, any teacher may have personal affection or disaffection, as all people. Both a student and a teacher are different and do not resemble from each other, and therefore it is impossible for everyone to take everything in the same way. The teacher's approach to each student must be different [1, 31-32].

Thomas Gordon emphasized that teachers' perception of students also depends mostly on the situation or environment in which students' behavior manifests itself. Sometimes such behavior of students is supposed to be unacceptable, although in any other situation there would be no claims to it. For example, most of the teachers perceive normally students' quarrels and misunderstandings outside the auditorium like it is all right, but they can not accept such students' behavior in an educational establishment. Therefore, we can conclude that the current situation or surrounding environment determines the teachers' attitude to students at a certain point $[1,32]$.

Considering the obstacles on the way of establishing effective relationships between teachers and students, let us recall the demonstrative exactingness and nonexactingness distinguished by Thomas Gordon. As the scientist noted, sometimes teachers are forced to pretend that they are satisfied with the students' behavior, which they are actually dissatisfied with. Or, on the contrary, the teachers pretend that they are satisfied with the students' behavior, although in other situations they would not have any complaints to it. Overusing such words as "must" and "obliged", teachers drive themselves into a trap of abuse [1, 32-33].

If students' behavior annoys teachers, but they pretend to consider it acceptable or, on the contrary, pretend to consider it unacceptable only because "it is necessary", then some misunderstandings may arrise between teachers and students and, as a result, deterioration in the relationships [1, 33-34].

The teachers' insincerity can be found in the double standards too. Sometimes there are cases when separate rules for teachers and separate rules for students hold. Offering privileges and freedom to teachers, and denying students' rights, the educational establishment turns into a complex ethical problem [1, 35-36].

Thomas Gordon believed that the last serious obstacle is the inability to distinguish the "affiliation" of the problem, that is, when the problem "belongs" to the teacher, and when - to the student. If unacceptable behavior of the student is incompatible with the realization of educational tasks, disturbs the teacher and displeases him, it becomes obvious that the teacher has a problem, that is, such behavior turns into the teacher's problem. The problem of another quality is defined when, for example, the student confesses to the teacher that he is dissatisfied with the behavior of one of his relatives... and for him it really is a problem. This problem "belongs" exactly to the student [1, 36-37].

It should be noted that the difficulties in identifying affiliation of "acquired problems" are one of the biggest obstacles on the way of achieving mutual understanding between teachers and students, and on the way of establishing positive relationships between them. Thomas Gordon emphasized that it is important for teachers to learn how to recognize the affiliation of problems $[1,37$ 39], because depending on this, they must behave completely differently. Teachers can separate their own problems from students' problems if they ask themselves the following questions: "Does the students' behavior influence me? Why do I consider it unacceptable? Does it prevent me from achieving my goals? Perhaps I used to another behavior of this student, and therefore his current behavior contradicts my expectations?" [1, 38-39]. If the answer to the second question is positive, the problem belongs to the student. If the answer to the first question is positive, the problem belongs to the teacher [1, 36-40]. It should be noted that sometimes both participants of the pedagogical process have problems. For example, sometimes students have problems which do not have a solution at all, and at times students behave so that their behavior disturbs the teachers and contradicts their views and wishes [1, 38-39].

Many teachers do not know what to do when students have problems. Some of the teachers believe that giving advice is not within their responsibilities. There are also teachers who think that an educational establishment should only organize the educational process. Many teachers relate to their students' problems, just as supervisors relate to the problems of their inferiors: if problems arise at home, they should be left at home as well [1, 42]. From Thomas Gordon's point of view, such opinion is 
false. Not all problems can be left without a solution, because they already exist, and certainly hinder the pedagogical process. In turn, students can not disclose their educational abilities in full because of current problems [1, 42-43].

Conclusions and prospects for further scientific research. Thus, in the process of pedagogical interaction between teachers and students there is their personal contact and logical alternating influence on each other, as a result of which there are mutual changes in their behavior and, thereafter, their activities.

Thomas Gordon emphasized such way of organizing pedagogical interaction between teachers and students, where both participants act as equal partners to the best of their knowledge and capabilities. To our mind, this way of organizing pedagogical interaction, when it manifests itself in the form of cooperation, and mutual agreement and solidarity in understanding the goals of the joint activity and the ways of attaining it are achieved by both parties, is an example of a humanistically-oriented pedagogical process.

Among the main ways of improving pedagogical communication and pedagogical interaction, we can underline the following: the study of psychological and pedagogical literature; the development of pedagogical, communicative and oratory abilities; the observing the interlocutor and his actions; regular communication; social activity.

\section{REFERENCES}

1. Gordon Th. Teacher Effectiveness Training. The Program Proven to Help Teachers Bring Out the Best in Students of All Ages. / Th. Gordon. - Three rivers press. New York. 2003. $-344 \mathrm{p}$.

2. Галузяк В. Основні характеристики ефективного стилю педагогічного спілкування / В. Галузяк // Наукові записки / - Вип. 32. - Вінниця. - С. 30-34

3. Isaieva $S$. The role of pedagogical strategies of effective communication in the process of teacher interaction with stu- dents / S. Isaieva // Science and Education a New Dimension: Pedagogy and Psychology. - V. (51), Issue 112. - Budapest, Hungary. - 2017. - P.19-21

4. Побірченко Н. Компетентнісний підхід у вищій школі: теоретичний аспект / Н. Побірченко // Освіта та педагогічна наука. - 2012. - № 3. - С. 24-31.

5. Зязюн І. Філософія педагогічної дії / І.Зязюн // Монографія. - Черкаси. - 2008. - 608 с.

\section{REFERENCES}

2. Haluzyak V. Main characteristics of the effective style of pedagogical communication / V. Haluzyak // Scientific Notes. - Issue 32. - Vinnytsia. - P. 30-34

4. Pobirchenko N. Competency approach in higher education:

theoretical aspect / N. Pobirchenko // Education and pedagogical science. - 2012. - № 3. - P. 24-31

5. Zyazyun I. Philosophy of Pedagogical Action / I. Zyazyun // Monograph. - Cherkasy. - 2008. -608 p. 